\section{Review Article}

\section{Check for updates}

\section{OPEN ACCESS}

Received: Nov 20, 2018

Accepted: Dec 26, 2018

Yoo YJ, Perinpanayagam H, Oh S, Kim AR, Han SH, Kum KY

*Correspondence to

Kee-Yeon Kum, DDS, MSD, PhD

Professor, Department of Conservative Dentistry, Dental Research Institute, Seoul Dental Hospital for Disabled, Seoul National University Dental Hospital, School of Dentistry, Seoul National University, 101 Daehak-ro, Jongno-gu, Seoul 03080, Korea.

E-mail: kum6139@snu.ac.kr

Copyright (c) 2019. The Korean Academy of Conservative Dentistry

This is an Open Access article distributed under the terms of the Creative Commons Attribution Non-Commercial License (https:// creativecommons.org/licenses/by-nc/4.0/) which permits unrestricted non-commercial use, distribution, and reproduction in any medium, provided the original work is properly cited.

Funding

This work was supported by the Korea Health Technology R\&D Project through the Korea Health Industry Development Institute (KHIDI), funded by the Ministry of Health \& Welfare (HI17C1377), Republic of Korea.

Conflict of Interest

No potential conflict of interest relevant to this article was reported.

\title{
Endodontic biofilms: contemporary and future treatment options
}

\section{Yeon-Jee Yoo (D), Hiran Perinpanayagam (1), ${ }^{2}$ Soram Oh $\left(\mathbb{D},,^{3}\right.$ A-Reum Kim $\left(\mathbb{D},{ }^{4}\right.$ Seung-Hyun Han (10, ${ }^{4}$ Kee-Yeon Kum (i) ${ }^{*}$}

\author{
'Department of Conservative Dentistry, Dental Research Institute, School of Dentistry, Seoul National \\ University, Seoul, Korea \\ ${ }^{2}$ Division of Restorative Dentistry, Schulich School of Medicine \& Dentistry, University of Western Ontario, \\ London, Canada \\ ${ }^{3}$ Department of Conservative Dentistry, School of Dentistry, Kyung Hee University, Seoul, Korea \\ ${ }^{4}$ Department of Oral Microbiology and Immunology, Dental Research Institute and BK21 Plus Program, \\ School of Dentistry, Seoul National University, Seoul, Korea
}

\section{ABSTRACT}

Apical periodontitis is a biofilm-mediated infection. The biofilm protects bacteria from host defenses and increase their resistance to intracanal disinfecting protocols. Understanding the virulence of these endodontic microbiota within biofilm is essential for the development of novel therapeutic procedures for intracanal disinfection. Both the disruption of biofilms and the killing of their bacteria are necessary to effectively treat apical periodontitis. Accordingly, a review of endodontic biofilm types, antimicrobial resistance mechanisms, and current and future therapeutic procedures for endodontic biofilm is provided.

Keywords: Antimicrobial resistance; Endodontic biofilm; Intracanal disinfection; Lactobacillus; Lipoteichoic acid

\section{ENDODONTIC BIOFILMS}

Biofilms are sessile multicellular microbial communities where microbes are enmeshed in a self-made extracellular polymeric substance (EPS, usually a polysaccharide), and firmly attached to surfaces [1]. These surfaces include root canal walls that provide a niche for bacteria $[2,3]$. Despite intracanal disinfection and a drastically changed environment, bacteria can be detected in post-treatment samples.

Biofilm formation is dependent on a surface conditioning layer, the properties of which determine microbial attachment and composition, as microbes within a planktonic phase are delivered [3]. Bacterial attachment to the substrate is dependent on surface energy, temperature, $\mathrm{pH}$, fluid flow rate, duration of contact, surface hydrophobicity, and nutrient availability [4]. Bacterial structures such as pili, flagella, EPS and polysaccharide-specific adhesins/ligands are important for adherence [5]. Proliferation and metabolism of attached microorganism creates structurally organized mixed microbial communities [3], and this monolayer then attracts secondary colonizers that form microcolonies and the final biofilm structure [6,7].

In endodontics, 4 types of biofilms, including intracanal, extraradicular, periapical, and biomaterial-centered biofilms were reported $[4,8]$. Nair reported that despite 


\section{Author Contributions}

Conceptualization: Yoo YJ, Han SH, Kum KY; Data curation: Yoo YJ, Kim AR, Perinpanayagam H; Formal analysis: Yoo YJ, Kim AR; Funding acquisition: Kum KY Investigation: Yoo YJ, Kim AR; Methodology: Perinpanayagam $\mathrm{H}$, Kum KY; Project administration: Kum KY; Resources: Perinpanayagam H, Kim AR; Software: Kim AR, Oh S; Supervision: Han SH, Kum KY; Validation: Han SH, Kum KY; Visualization: Yoo YJ, Kim AR, Kum KY; Writing - original draft: Yoo YJ, Kim AR, Kum KY; Writing - review \& editing: Yoo YJ, Perinpanayagam $\mathrm{H}$, Han SH, Kum KY.

ORCID IDS

Yeon-Jee Yoo (D)

https://orcid.org/0000-0002-3931-7668

Hiran Perinpanayagam (D)

https://orcid.org/0000-0001-6484-5932

Soram Oh (iD)

https://orcid.org/0000-0002-8843-2144 A-Reum Kim (iD)

https://orcid.org/0000-0003-4246-4316 Seung-Hyun Han (ID)

https://orcid.org/0000-0001-9418-9278 Kee-Yeon Kum (D)

https://orcid.org/0000-0002-3032-3498 instrumentation, irrigation, and obturation for single-visit treatment of mandibular first molars with primary apical periodontitis, microorganisms persisted within biofilms in untouched areas of canals and isthmuses [9], which is called as an intracanal biofilms.

Extradicular biofilms were reported in teeth with asymptomatic apical periodontitis, as well as those with chronic apical abscesses and sinus tract [4,8]. Ricucci et al. [10] discovered calculus-like deposits on root tips of teeth with secondary (post-treatment) apical periodontitis. Noiri et al. [11] found glycocalyx-like structures had almost completely covered gutta-percha cones recovered from beyond the apex, and bacteria on the external root surfaces in the extracted teeth in cases of 'refractory periapical pathosis'.

Certain strains can survive and infect periapical tissues as periapical biofilms [2]. Propionibacterium propionicum and various Actinomyces have been demonstrated in asymptomatic periapical lesions refractory to endodontic treatment [12]. Some Actinomyces have fimbriae for coaggregation, adherence to canal walls and dentinal debris forced through the apical foramen during treatment [13]. Bacteria may evade host defenses by building cohesive colonies including many branching and filamentous bacteria enmeshed in proteinpolysaccharide matrix [13].

Bacteria can also adhere to artificial biomaterial surfaces and form biofilm structures [14] that cause biomaterial-centered infections. Gram-positive facultative anaerobes with serum colonize and form EPS on gutta-percha [14]. These biofilms on obturating materials can be both intra- and extra-radicular, when the material has extruded beyond the apex.

\section{MECHANISMS OF ANTIMICROBIAL RESISTANCE}

The polysaccharide matrix in biofilms retards diffusion of antibiotics and inactivating extracellular enzymes such as $\beta$-lactamase may become concentrated [15]. Microbial cells communicate by quorum sensing to encourage the growth of species beneficial to biofilm structure $[1,16]$. Subpopulations within a biofilm can alter gene expression to remain protected [17]. Cells remain interiorly where they are protected from medicaments that act only on the microorganisms in the biofilms periphery. Bacterial cells grow more slowly with less metabolism in biofilms than when planktonic, and thereby elude antimicrobial agents [15]. They halt growth with nutrient depletion or waste product accumulation, further protecting them from antibiotics [17]. The altered $\mathrm{pH}$ and oxygen level within biofilms may further impair antibiotics [18].

\section{CURRENT AND FUTURE THERAPEUTIC STRATEGIES AGAINST ENDODONTIC BIOFILM}

\section{Irrigants for biofilm eradication}

Microorganisms grown within biofilms are 1,000-1,500 times more resistant to antimicrobials than planktonic bacteria $[6,19]$. Sodium hypochlorite $(\mathrm{NaOCl})$ has been widely used as an endodontic irrigant due to its potent antimicrobial action and necrotic tissue dissolving property. Regarding the recalcitrant bacteria, mostly Enterococcus faecalis (E. faecalis) biofilm, it was reported that treatment of E. faecalis lipoteichoic acid (LTA) with $\mathrm{NaOCl}$ resulted in the impairment of immunostimulating activity by the delipidation of 
glycolipid moiety structure [20]. $\mathrm{NaOCl}$ could impair toll like receptor 2 activation of $E$. faecalis and induce inflammatory mediators, and damage the LTA structure, potentially through deacylation [20]. Furthermore, $\mathrm{NaOCl}$ is the most effective antimicrobial irrigant against multi-species biofilm [21]. Given that the dual-species biofilms or the aged biofilms were more resistant to $\mathrm{NaOCl}$ than monospecies biofilms or the young biofilms [22], many researches found that high concentratin $\mathrm{NaOCl}$ was the only irrigant effective in disrupting multi-species biofilm and eradicating bacterial cells [23-26].

Chlorhexidine (CHX) digluconate is a broad spectrum antimicrobial disinfectant that has antimicrobial substantive activity [27-29], and thus has been widely used as an auxiliary canal irrigant or a canal soaking agent against $E$. faecalis biofilms [30,31]. A recent study demonstrated that CHX attenuates the activity of E. faecalis LTA [32]. Kim et al. [33] compared the antimicrobial activity of alexidine $(1 \%)$ and $\mathrm{CHX}(2 \%)$ on E. faecalis by using dentin block model according to soaking time ( 5 and 10 minutes). And they found that there was no significant difference in the number of bacteria adhering after the first minute of exposure and the most effective irrigant at disrupting biofilms was $\mathrm{NaOCl}$ [25]. Despite these antimicrobial activities, CHX cannot be used as main root canal irrigant because it does not have tissue solvent activity [30].

In addition to smear layer removal, EDTA irrigation can be beneficial in disruption of biofilm. Ozdemir et al. [34] demonstrated that combination of EDTA and $\mathrm{NaOCl}$ significantly reduced the amount of intracanal biofilm in both young and old aged biofilms. Soares $e t$ al. [35] reported that the NaOCl-EDTA alternating irrigation was a promising regimen for elimination of intracanal E. faecalis biofilms.

\section{Intracanal medicament for biofilm eradication}

\section{Calcium hydroxide}

Calcium hydroxide $(\mathrm{CH})$ is a widely used intracanal medicament that has broad antimicrobial activity, which is dependent on the release of aqueous hydroxyl ions to raise $\mathrm{pH}$ so that microbes cannot survive [36]. Elevated $\mathrm{pH}$ alters membrane integrity, and the hydroxyl ions are highly reactive with biomolecules [37].

Yet, intracanal $\mathrm{CH}$ was reported to be ineffective in preventing E. faecalis biofilm formation in root canals [19], while still being effective in eliminating their biofilm [38]. Brändle et al. [39] evaluated the effects of growth condition (planktonic, mono- and multi-species biofilms) on the susceptibility of E. faecalis, Streptococcus sobrinus (S. sobrinus), Candida albicans (C. albicans), Actinomyces naeslundii (A. naeslundii), and Fusobacterium nucleatum to alkaline stress. The findings showed that planktonic microorganisms were most susceptible; only E. faecalis and C. albicans survived in saturated solution for 10 minutes, and the latter also survived for 100 minutes [39]. Dentin adhesion was the major factor in improving the resistance of $E$. faecalis and $A$. naeslundii to $\mathrm{CH}$, whereas the multispecies context in a biofilm was the major factor in promoting resistance of $S$. sobrinus to the disinfectant. In contrast, the $C$. albicans response to $\mathrm{CH}$ was not influenced by growth conditions [39].

In addition to the effect of hydroxyl ion, damage in the lipid moieties of bacterial virulence factors composed of glycolipids might be a unique detoxification mechanism of $\mathrm{CH}$. E. faecalis is known to be resistant to $\mathrm{CH}$, owing to their proton pump for internal $\mathrm{pH}$ maintenance and inhibitory dentin buffering effect. However, it was recently found that $\mathrm{CH}$ could attenuate 
the abilities of not only E. faecalis but also its LTA to stimulate murine macrophages, and could reduce TNF- $\alpha$ or NO production [40]. As an underlying mechanism, Baik et al. [40] reported that $\mathrm{CH}$ could deacylate the LTA from $E$. faecalis, resulting in the impairment of LTA immunostimulating activity. $\mathrm{CH}$ can also inactivate lipopolysaccharide (LPS) in gramnegative bacteria, via hydrolysis of fatty acid in the lipid A moiety [41-44].

\section{Chlorhexidine}

Positively charged CHX molecules interact with negatively charged membrane phospholipids to enter and permeabilize microbial cells [45]. It was reported that CHX could alter cell walls and nucleoprotein coagulation, even in C. albicans [46,47]. In dentin block model, CHX showed superior antifungal activity compared to $\mathrm{CH}$, up to $400 \mu \mathrm{m}$ depth dentinal tubules [46]. Additionally, CHX binds to hydroxyapatite and reduces microbial colonization on dentin surfaces, which provides substantive antimicrobial activity [27].

Subsequent analyses of biofilm spatial arrangements showed differences between the singleand dual-species biofilms in microstructural alterations in response to CHX exposure. Dual-species biofilms, but not single-species biofilms, had formed distinct clusters that were considered to account for the increased resistance to CHX [48].

\section{Human beta defensins}

Human beta defensins (HBDs) are cationic antimicrobial peptides that are critical host defense against microbes [49]. They bind to the negatively charged molecules on bacterial surface and disrupt bacterial membranes [50]. HBDs differ in amino acid sequences, structure, cysteine residues with disulfide bridges, charge, and affinity for bacterial membrane targets such as LPS in gram-negatives and LTA in gram-positives [51]. The antimicrobial effects of HBDs differ with bacterial strains due to variations in their LPS and LTA structure [52]. HBD-3 is strongly inhibitory, whereas HBD-1, -2, and -4 have weak antimicrobial effects on E. faecalis [53].

HBD-1, $-2,-3$, and -4 are produced in normal and inflamed dental pulp [54,55]. They may protect the pulp from inflammation induced by LTA of gram-positive bacteria and LPS of gram-negative bacteria [56]. Synthetic HBD-3 consisting of the $C$ terminal 15 amino acids (HBD3-C15) was reported to be effective for disinfecting endodontic biofilm including $C$. albicans $[46,57,58]$.

\section{Triple antibiotic paste}

Triple antibiotic paste (TAP), a mixture of metronidazole, ciprofloxacin, and minocycline, is widely used in regenerative endodontic procedure (REP). It is effective on infected dentin, intracanal biofilms, and the majority of endodontic pathogens [59-62]. But its toxicity to residual undifferentiated cells and periapical tissues limits its application in REP.

\section{Laser-assisted eradication of biofilms}

A low power laser directed at the access cavity combined with a photosensitizing agent was bactericidal on $S$. intermedius biofilms in root canals, but less effective than $\mathrm{NaOCl}(3 \%)$ irrigation [63]. Er:YAG laser was effective on apical root apex biofilms in vitro [64]. However, endodontic pathogens in biofilms were difficult to eradicate despite direct laser exposure ex vivo [65]. Er:YAG laser was effective against biofilms of A. naeslundii, E. faecalis, Lactobacillus casei (L. casei), Propionibacterium acnes, F. nucleatum, Porphyromonas gingivalis, or Prevotella nigrescens, in vitro, but not against biofilms of $L$. casei [66]. 


\section{Effect of Lactobacillus plantarum LTA}

Lactobacillus plantarum (L. plantarum) is a probiotic [67] that is known to have antiinflammatory and anti-biofilm effect [68]. Bacterial cell wall components especially LTA inhibit Streptococcus mutans (S. mutans), E. faecalis, and Staphylococcus aureus (S. aureus) biofilm formation by controlling gene expression, quorum sensing, and inhibiting exopolysaccharides production [69-71]. Furthermore, L. plantarum LTA also disrupted preformed biofilm of $E$. faecalis and $S$. aureus [69,71]. Interestingly, L. plantarum LTA reduced not only mono-species biofilm, but also multi-species biofilm consisting of $A$. naeslundii, E. faecalis, Lactobacillus salivarius, and S. mutans [72], and it also cooperatively enhanced disruption of oral multispecies biofilm when combined with $\mathrm{CH}$ and $\mathrm{CHX}$ intracanal medicaments (unpublished data).

\section{Effect of nanoparticles, photodynamic therapy, ozone, and enzymes}

Nanoparticles synthesized from powders of silver, copper oxide, and zinc oxide, and other powders have broad antimicrobial applications [73]. These nanoparticles generate reactive oxygen species (ROS) that are cytotoxic for bacteria. Higher surface area and more charge density mean greater potential for bacterial interactions. Numerous positively charged nanoparticles accumulate on negatively charged bacterial cell membranes, which increase permeability to destroy cells [74-76]. Additionally, cationic nanoparticles adhere to negatively charged dentin surface to prevent biofilm formation [77].

In photodynamic therapy (PDT), a photosensitizer is preferentially localized in tissue and subsequently activated by appropriate wavelength light to generate reactive oxygen that kill bacteria [78]. There have been numerous in vitro studies on PDT in root canal disinfection [79-83]. However, penetration of the activating light and the photosensitizer may be limited within root canal structures. When microorganisms were sensitized with methylene blue ( 25 $\mu \mathrm{g} / \mathrm{mL}, 5$ minutes), all bacterial species except $E$. faecalis (53\% killing) were destroyed. When this was followed by the addition of red light $\mathrm{CH}\left(222 \mathrm{~J} / \mathrm{cm}^{2}\right)$ with an optical fiber, almost all $(97 \%)$ E. faecalis biofilm bacteria in root canals were eliminated [83].

Ozone gas (HealOzone, KaVo, Biberach, Germany) has yielded inconsistent result in destroying endodontic pathogens. These inconsistencies may have been due to variation in concentration and duration of application [84-86]. There is conflicting evidence on its antimicrobial efficacy and reduced effects on sessile versus planktonic bacteria [87].

Natural plant extracts such as polyphenols, Morinda citrifolia, and turmeric, as well as enzymes, such as dispersin $\mathrm{B}$ and proteinase $\mathrm{K}$, have been proposed for treating biofilm medicated infections. But studies are needed to demonstrate their efficacy.

\section{CONCLUSIONS}

Endodontic infection is caused by the surface-associated growth of microorganisms. Applying the biofilm concept to endodontic microbiology helps to understand the pathogenic potential of the root canal microbiota and to form the basis of new approaches in root canal disinfection. Recent developments in biocompatible intracanal medicaments including synthetic HBDs and $L$. plantarum LTA could open up new avenues as an ideal therapeutic agent to eradicate endodontic biofilm. 


\section{REFERENCES}

1. Siqueira JF Jr, Rôças IN. Clinical implications and microbiology of bacterial persistence after treatment procedures. J Endod 2008;34:1291-1301.e3.

PUBMED | CROSSREF

2. Chavez de Paz LE. Redefining the persistent infection in root canals: possible role of biofilm communities. J Endod 2007;33:652-662. PUBMED | CROSSREF

3. Svensater G, Bergenholtz G. Biofilms in endodontic infections. Endod Topics 2004;9:27-36. CROSSREF

4. Ingle JI, Bakland LK, Baumgartner JC. Ingle's Endodontics. 6th ed. Lewiston, PA: PMPH-USA; 2008. p268-285.

5. Grenier D, Mayrand D. Nutritional relationships between oral bacteria. Infect Immun 1986;53:616-620. PUBMED

6. Costerton JW, Stewart PS, Greenberg EP. Bacterial biofilms: a common cause of persistent infections. Science 1999;284:1318-1322. PUBMED | CROSSREF

7. Cowan MM, Taylor KG, Doyle RJ. Energetics of the initial phase of adhesion of Streptococcus sanguis to hydroxylapatite. J Bacteriol 1987;169:2995-3000. PUBMED | CROSSREF

8. Mohammadi Z, Palazzi F, Giardino L, Shalavi S. Microbial biofilms in endodontic infections: an update review. Biomed J 2013;36:59-70. PUBMED | CROSSREF

9. Nair PN, Henry S, Cano V, Vera J. Microbial status of apical root canal system of human mandibular first molars with primary apical periodontitis after "one-visit" endodontic treatment. Oral Surg Oral Med Oral Pathol Oral Radiol Endod 2005;99:231-252. PUBMED | CROSSREF

10. Ricucci D, Martorano M, Bate AL, Pascon EA. Calculus-like deposit on the apical external root surface of teeth with post-treatment apical periodontitis: report of two cases. Int Endod J 2005;38:262-271. PUBMED | CROSSREF

11. Noiri Y, Ehara A, Kawahara T, Takemura N, Ebisu S. Participation of bacterial biofilms in refractory and chronic periapical periodontitis. J Endod 2002;28:679-683. PUBMED | CROSSREF

12. Siqueira JF Jr. Periapical actinomycosis and infection with Propionobacterium propionicum. Endod Topics 2003;6:78-95. CROSSREF

13. Figdor D, Sjögren U, Sörlin S, Sundqvist G, Nair PN. Pathogenicity of Actinomyces israelii and Arachnia propionica: experimental infection in guinea pigs and phagocytosis and intracellular killing by human polymorphonuclear leukocytes in vitro. Oral Microbiol Immunol 1992;7:129-136. PUBMED | CROSSREF

14. Wilson M. Susceptibility of oral bacterial biofilms to antimicrobial agents. J Med Microbiol 1996;44:79-87. PUBMED | CROSSREF

15. Dunavant TR, Regan JD, Glickman GN, Solomon ES, Honeyman AL. Comparative evaluation of endodontic irrigants against Enterococcus faecalis biofilms. J Endod 2006;32:527-531. PUBMED | CROSSREF

16. Larsen T. Susceptibility of Porphyromonas gingivalis in biofilms to amoxicillin, doxycycline and metronidazole. Oral Microbiol Immunol 2002;17:267-271. PUBMED | CROSSREF

17. Portenier I, Waltimo TM, Haapasalo M. Enterococcus faecalis: the root canal survivor and 'star' in posttreatment disease. Endod Topics 2003;6:135-159. CROSSREF

18. Athanassiadis B, Abbott PV, Walsh LJ. The use of calcium hydroxide, antibiotics and biocides as antimicrobial medicaments in endodontics. Aust Dent J 2007;52:S64-S82. PUBMED | CROSSREF

19. Distel JW, Hatton JF, Gillespie MJ. Biofilm formation in medicated root canals. J Endod 2002;28:689-693. PUBMED | CROSSREF

20. Hong SW, Baik JE, Kang SS, Kum KY, Yun CH, Han SH. Sodium hypochlorite inactivates lipoteichoic acid of Enterococcus faecalis by deacylation. J Endod 2016;42:1503-1508.

PUBMED | CROSSREF 
21. Spratt DA, Pratten J, Wilson M, Gulabivala K. An in vitro evaluation of the antimicrobial efficacy of irrigants on biofilms of root canal isolates. Int Endod J 2001;34:300-307. PUBMED | CROSSREF

22. Ozok AR, Wu MK, Luppens SB, Wesselink PR. Comparison of growth and susceptibility to sodium hypochlorite of mono- and dual-species biofilms of Fusobacterium nucleatum and Peptostreptococcus (micromonas) micros. J Endod 2007;33:819-822. PUBMED | CROSSREF

23. Clegg MS, Vertucci FJ, Walker C, Belanger M, Britto LR. The effect of exposure to irrigant solutions on apical dentin biofilms in vitro. J Endod 2006;32:434-437.

PUBMED | CROSSREF

24. Giardino L, Ambu E, Savoldi E, Rimondini R, Cassanelli C, Debbia EA. Comparative evaluation of antimicrobial efficacy of sodium hypochlorite, MTAD, and Tetraclean against Enterococcus faecalis biofilm. J Endod 2007;33:852-855. PUBMED | CROSSREF

25. Bryce G, O'Donnell D, Ready D, Ng YL, Pratten J, Gulabivala K. Contemporary root canal irrigants are able to disrupt and eradicate single- and dual-species biofilms. J Endod 2009;35:1243-1248. PUBMED | CROSSREF

26. Baca P, Junco P, Arias-Moliz MT, González-Rodríguez MP, Ferrer-Luque CM. Residual and antimicrobial activity of final irrigation protocols on Enterococcus faecalis biofilm in dentin. J Endod 2011;37:363-366. PUBMED | CROSSREF

27. Parsons GJ, Patterson SS, Miller CH, Katz S, Kafrawy AH, Newton CW. Uptake and release of chlorhexidine by bovine pulp and dentin specimens and their subsequent acquisition of antibacterial properties. Oral Surg Oral Med Oral Pathol 1980;49:455-459. PUBMED | CROSSREF

28. Basrani B, Santos JM, Tjäderhane L, Grad H, Gorduysus O, Huang J, Lawrence HP, Friedman S. Substantive antimicrobial activity in chlorhexidine-treated human root dentin. Oral Surg Oral Med Oral Pathol Oral Radiol Endod 2002;94:240-245. PUBMED | CROSSREF

29. Baca P, Junco P, Arias-Moliz MT, Castillo F, Rodríguez-Archilla A, Ferrer-Luque CM. Antimicrobial substantivity over time of chlorhexidine and cetrimide. J Endod 2012;38:927-930. PUBMED | CROSSREF

30. Mohammadi Z, Abbott PV. The properties and applications of chlorhexidine in endodontics. Int Endod J 2009;42:288-302. PUBMED | CROSSREF

31. Gomes BP, Ferraz CC, Vianna ME, Berber VB, Teixeira FB, Souza-Filho FJ. In vitro antimicrobial activity of several concentrations of sodium hypochlorite and chlorhexidine gluconate in the elimination of Enterococcus faecalis. Int Endod J 2001;34:424-428. PUBMED | CROSSREF

32. Lee JK, Baik JE, Yun CH, Lee K, Han SH, Lee W, Bae KS, Baek SH, Lee Y, Son WJ, Kum KY. Chlorhexidine gluconate attenuates the ability of lipoteichoic acid from Enterococcus faecalis to stimulate toll-like receptor 2. J Endod 2009;35:212-215. PUBMED | CROSSREF

33. Kim HS, Woo Chang S, Baek SH, Han SH, Lee Y, Zhu Q, Kum KY. Antimicrobial effect of alexidine and chlorhexidine against Enterococcus faecalis infection. Int J Oral Sci 2013;5:26-31. PUBMED | CROSSREF

34. Ozdemir HO, Buzoglu HD, Calt S, Stabholz A, Steinberg D. Effect of ethylenediaminetetraacetic acid and sodium hypochlorite irrigation on Enterococcus faecalis biofilm colonization in young and old human root canal dentin: in vitro study. J Endod 2010;36:842-846. PUBMED | CROSSREF

35. Soares JA, Roque de Carvalho MA, Cunha Santos SM, Mendonça RM, Ribeiro-Sobrinho AP, Brito-Júnior M, Magalhães PP, Santos MH, de Macêdo Farias L. Effectiveness of chemomechanical preparation with alternating use of sodium hypochlorite and EDTA in eliminating intracanal Enterococcus faecalis biofilm. J Endod 2010;36:894-898. PUBMED | CROSSREF

36. Siqueira JF Jr. Strategies to treat infected root canals. J Calif Dent Assoc 2001;29:825-837. PUBMED

37. Siqueira JF Jr, Lopes HP. Mechanisms of antimicrobial activity of calcium hydroxide: a critical review. Int Endod J 1999;32:361-369.

PUBMED | CROSSREF 
38. Chai WL, Hamimah H, Cheng SC, Sallam AA, Abdullah M. Susceptibility of Enterococcus faecalis biofilm to antibiotics and calcium hydroxide. J Oral Sci 2007;49:161-166. PUBMED | CROSSREF

39. Brändle N, Zehnder M, Weiger R, Waltimo T. Impact of growth conditions on susceptibility of five microbial species to alkaline stress. J Endod 2008;34:579-582. PUBMED | CROSSREF

40. Baik JE, Jang KS, Kang SS, Yun CH, Lee K, Kim BG, Kum KY, Han SH. Calcium hydroxide inactivates lipoteichoic acid from Enterococcus faecalis through deacylation of the lipid moiety. J Endod 2011;37:191-196. PUBMED | CROSSREF

41. Safavi KE, Nichols FC. Effect of calcium hydroxide on bacterial lipopolysaccharide. J Endod 1993;19:76-78. PUBMED | CROSSREF

42. Barthel CR, Levin LG, Reisner HM, Trope M. TNF-alpha release in monocytes after exposure to calcium hydroxide treated Escherichia coli LPS. Int Endod J 1997;30:155-159. PUBMED | CROSSREF

43. Jiang J, Zuo J, Chen SH, Holliday LS. Calcium hydroxide reduces lipopolysaccharide-stimulated osteoclast formation. Oral Surg Oral Med Oral Pathol Oral Radiol Endod 2003;95:348-354. PUBMED | CROSSREF

44. Buck RA, Cai J, Eleazer PD, Staat RH, Hurst HE. Detoxification of endotoxin by endodontic irrigants and calcium hydroxide. J Endod 2001;27:325-327. PUBMED | CROSSREF

45. Bobichon H, Bouchet P. Action of chlorhexidine on budding Candida albicans: scanning and transmission electron microscopic study. Mycopathologia 1987;100:27-35. PUBMED | CROSSREF

46. Yoo YJ, Kwon I, Oh SR, Perinpanayagam H, Lim SM, Ahn KB, Lee Y, Han SH, Chang SW, Baek SH, Zhu Q, Kum KY. Antifungal effects of synthetic human beta-defensin-3-C15 peptide on Candida albicans-infected root dentin. J Endod 2017;43:1857-1861. PUBMED | CROSSREF

47. Krithikadatta J, Indira R, Dorothykalyani AL. Disinfection of dentinal tubules with $2 \%$ chlorhexidine, $2 \%$ metronidazole, bioactive glass when compared with calcium hydroxide as intracanal medicaments. J Endod 2007;33:1473-1476. PUBMED | CROSSREF

48. Kara D, Luppens SB, van Marle J, Ozok R, ten Cate JM. Microstructural differences between singlespecies and dual-species biofilms of Streptococcus mutans and Veillonella parvula, before and after exposure to chlorhexidine. FEMS Microbiol Lett 2007;271:90-97. PUBMED | CROSSREF

49. Zasloff M. Antimicrobial peptides of multicellular organisms. Nature 2002;415:389-395. PUBMED | CROSSREF

50. Selsted ME, Ouellette AJ. Mammalian defensins in the antimicrobial immune response. Nat Immunol 2005;6:551-557. PUBMED | CROSSREF

51. Schneider JJ, Unholzer A, Schaller M, Schäfer-Korting M, Korting HC. Human defensins. J Mol Med (Berl) 2005;83:587-595. PUBMED | CROSSREF

52. Lee SH, Jun HK, Lee HR, Chung CP, Choi BK. Antibacterial and lipopolysaccharide (LPS)-neutralising activity of human cationic antimicrobial peptides against periodontopathogens. Int J Antimicrob Agents 2010;35:138-145. PUBMED | CROSSREF

53. Lee SH, Baek DH. Antibacterial and neutralizing effect of human $\beta$-defensins on Enterococcus faecalis and Enterococcus faecalis lipoteichoic acid. J Endod 2012;38:351-356. PUBMED | CROSSREF

54. Yamaguchi Y, Nagase T, Makita R, Fukuhara S, Tomita T, Tominaga T, Kurihara H, Ouchi Y. Identification of multiple novel epididymis-specific beta-defensin isoforms in humans and mice. J Immunol 2002;169:2516-2523. PUBMED | CROSSREF

55. Paris S, Wolgin M, Kielbassa AM, Pries A, Zakrzewicz A. Gene expression of human beta-defensins in healthy and inflamed human dental pulps. J Endod 2009;35:520-523. PUBMED | CROSSREF

56. Giacometti A, Cirioni O, Ghiselli R, Mocchegiani F, Del Prete MS, Viticchi C, Kamysz W, ŁEmpicka E, Saba V, Scalise G. Potential therapeutic role of cationic peptides in three experimental models of septic shock. Antimicrob Agents Chemother 2002;46:2132-2136. PUBMED | CROSSREF 
57. Ahn KB, Kim AR, Kum KY, Yun CH, Han SH. The synthetic human beta-defensin-3 C15 peptide exhibits antimicrobial activity against Streptococcus mutans, both alone and in combination with dental disinfectants. J Microbiol 2017;55:830-836. PUBMED | CROSSREF

58. Lim SM, Ahn KB, Kim C, Kum JW, Perinpanayagam H, Gu Y, Yoo YJ, Chang SW, Han SH, Shon WJ, Lee W, Baek SH, Zhu Q, Kum KY. Antifungal effects of synthetic human $\beta$-defensin 3-C15 peptide. Restor Dent Endod 2016;41:91-97. PUBMED | CROSSREF

59. Windley W 3rd, Teixeira F, Levin L, Sigurdsson A, Trope M. Disinfection of immature teeth with a triple antibiotic paste. J Endod 2005;31:439-443. PUBMED | CROSSREF

60. Hoshino E, Kurihara-Ando N, Sato I, Uematsu H, Sato M, Kota K, Iwaku M. In-vitro antibacterial susceptibility of bacteria taken from infected root dentine to a mixture of ciprofloxacin, metronidazole and minocycline. Int Endod J 1996;29:125-130. PUBMED | CROSSREF

61. Sato I, Ando-Kurihara N, Kota K, Iwaku M, Hoshino E. Sterilization of infected root-canal dentine by topical application of a mixture of ciprofloxacin, metronidazole and minocycline in situ. Int Endod J 1996;29:118-124. PUBMED | CROSSREF

62. Ordinola-Zapata R, Bramante CM, Minotti PG, Cavenago BC, Garcia RB, Bernardineli N, Jaramillo DE, Hungaro Duarte MA. Antimicrobial activity of triantibiotic paste, $2 \%$ chlorhexidine gel, and calcium hydroxide on an intraoral-infected dentin biofilm model. J Endod 2013;39:115-118. PUBMED | CROSSREF

63. Seal GJ, Ng YL, Spratt D, Bhatti M, Gulabivala K. An in vitro comparison of the bactericidal efficacy of lethal photosensitization or sodium hyphochlorite irrigation on Streptococcus intermedius biofilms in root canals. Int Endod J 2002;35:268-274. PUBMED | CROSSREF

64. Araki AT, Ibraki Y, Kawakami T, Lage-Marques JL. Er:Yag laser irradiation of the microbiological apical biofilm. Braz Dent J 2006;17:296-299. PUBMED | CROSSREF

65. Bergmans L, Moisiadis P, Teughels W, Van Meerbeek B, Quirynen M, Lambrechts P. Bactericidal effect of Nd:YAG laser irradiation on some endodontic pathogens ex vivo. Int Endod J 2006;39:547-557. PUBMED | CROSSREF

66. Noiri Y, Katsumoto T, Azakami H, Ebisu S. Effects of Er:YAG laser irradiation on biofilm-forming bacteria associated with endodontic pathogens in vitro. J Endod 2008;34:826-829. PUBMED | CROSSREF

67. Isolauri E. Probiotics in human disease. Am J Clin Nutr 2001;73:1142S-1146S. PUBMED | CROSSREF

68. Söderling EM, Marttinen AM, Haukioja AL. Probiotic lactobacilli interfere with Streptococcus mutans biofilm formation in vitro. Curr Microbiol 2011;62:618-622. PUBMED | CROSSREF

69. Ahn KB, Baik JE, Yun CH, Han SH. Lipoteichoic acid inhibits Staphylococcus aureus biofilm formation. Front Microbiol 2018;9:327. PUBMED | CROSSREF

70. Ahn KB, Baik JE, Park OJ, Yun CH, Han SH. Lactobacillus plantarum lipoteichoic acid inhibits biofilm formation of Streptococcus mutans. PLoS One 2018;13:e0192694. PUBMED | CROSSREF

71. Jung S, Park OJ, Kim AR, Ahn KB, Lee D, Kum KY, Yun CH, Han SH. Lipoteichoic acids of lactobacilli inhibit Enterococcus faecalis biofilm formation and disrupt the preformed biofilm. J Microbiol 2019 Jan 22. doi: 10.1007/s12275-019-8538-4. [Epub ahead of print] PUBMED | CROSSREF

72. Kim AR, Ahn KB, Yoon SH, Yoo YJ, Perinpanayagam H, Kum KY, Han SH. Lactobacillus plantarum lipoteichoic acid inhibits oral multispecies biofilm. J Endod. 2019 Jan. doi: 10.1016/j.joen.2018.12.007. [accepted].

73. Kim JS, Kuk E, Yu KN, Kim JH, Park SJ, Lee HJ, Kim SH, Park YK, Park YH, Hwang CY, Kim YK, Lee YS, Jeong DH, Cho MH. Antimicrobial effects of silver nanoparticles. Nanomedicine (Lond) 2007;3:95-101. PUBMED | CROSSREF

74. Sawai J. Quantitative evaluation of antibacterial activities of metallic oxide powders $(\mathrm{ZnO}, \mathrm{MgO}$ and $\mathrm{CaO})$ by conductimetric assay. J Microbiol Methods 2003;54:177-182.

PUBMED | CROSSREF 
75. Beard SJ, Hughes MN, Poole RK. Inhibition of the cytochrome bd-terminated NADH oxidase system in Escherichia coli K-12 by divalent metal cations. FEMS Microbiol Lett 1995;131:205-210. PUBMED | CROSSREF

76. Feng QL, Wu J, Chen GQ, Cui FZ, Kim TN, Kim JO. A mechanistic study of the antibacterial effect of silver ions on Escherichia coli and Staphylococcus aureus. J Biomed Mater Res 2000;52:662-668. PUBMED | CROSSREF

77. Kishen A, Sum CP, Mathew S, Lim CT. Influence of irrigation regimens on the adherence of Enterococcus faecalis to root canal dentin. J Endod 2008;34:850-854. PUBMED | CROSSREF

78. Dai T, Huang YY, Hamblin MR. Photodynamic therapy for localized infections--state of the art. Photodiagnosis Photodyn Ther 2009;6:170-188. PUBMED | CROSSREF

79. Meire MA, De Prijck K, Coenye T, Nelis HJ, De Moor RJ. Effectiveness of different laser systems to kill Enterococcus faecalis in aqueous suspension and in an infected tooth model. Int Endod J 2009;42:351-359. PUBMED | CROSSREF

80. George S, Kishen A. Photophysical, photochemical, and photobiological characterization of methylene blue formulations for light-activated root canal disinfection. J Biomed Opt 2007;12:034029.

PUBMED | CROSSREF

81. George S, Kishen A. Influence of photosensitizer solvent on the mechanisms of photoactivated killing of Enterococcus faecalis. Photochem Photobiol 2008;84:734-740. PUBMED | CROSSREF

82. George S, Kishen A. Augmenting the antibiofilm efficacy of advanced noninvasive light activated disinfection with emulsified oxidizer and oxygen carrier. J Endod 2008;34:1119-1123. PUBMED | CROSSREF

83. Soukos NS, Chen PS, Morris JT, Ruggiero K, Abernethy AD, Som S, Foschi F, Doucette S, Bammann LL, Fontana CR, Doukas AG, Stashenko PP. Photodynamic therapy for endodontic disinfection. J Endod 2006;32:979-984. PUBMED | CROSSREF

84. Nagayoshi M, Kitamura C, Fukuizumi T, Nishihara T, Terashita M. Antimicrobial effect of ozonated water on bacteria invading dentinal tubules. J Endod 2004;30:778-781.

PUBMED | CROSSREF

85. Arita M, Nagayoshi M, Fukuizumi T, Okinaga T, Masumi S, Morikawa M, Kakinoki Y, Nishihara T. Microbicidal efficacy of ozonated water against Candida albicans adhering to acrylic denture plates. Oral Microbiol Immunol 2005;20:206-210. PUBMED | CROSSREF

86. Hems RS, Gulabivala K, Ng YL, Ready D, Spratt DA. An in vitro evaluation of the ability of ozone to kill a strain of Enterococcus faecalis. Int Endod J 2005;38:22-29. PUBMED | CROSSREF

87. Azarpazhooh A, Limeback $\mathrm{H}$. The application of ozone in dentistry: a systematic review of literature. J Dent 2008;36:104-116.

PUBMED | CROSSREF 